\title{
Endocrine therapy inhibits proliferation and migration, promotes apoptosis and suppresses survivin protein expression in colorectal cancer cells
}

\author{
QING-JIAN OU ${ }^{1,2 *}$, XIAO-JUN WU ${ }^{1 *}$, JIAN-HONG PENG ${ }^{1}$, RONG-XIN ZHANG ${ }^{1}$, \\ ZHEN-HAI LU ${ }^{1}$, WU JIANG ${ }^{1}$, LIN ZHANG ${ }^{3}$, ZHI-ZHONG PAN ${ }^{1}$, DE-SEN WAN ${ }^{1}$ and YU-JING FANG ${ }^{1,2}$ \\ Departments of ${ }^{1}$ Colorectal Surgery, ${ }^{2}$ Experimental Research and ${ }^{3}$ Clinical Laboratory, \\ Sun Yat-sen University Cancer Centre, State Key Laboratory of Oncology in South China, Collaborative \\ Innovation Centre for Cancer Medicine, Guangzhou, Guangdong 510060, P.R. China
}

Received February 29, 2016; Accepted March 9, 2017

DOI: $10.3892 / \mathrm{mmr} .2017 .7375$

\begin{abstract}
The majority of colorectal cancers (CRCs) are hormone-dependent. Thus, endocrine therapy has become an attractive strategy to treat CRC. The aim of the present study was to investigate the inhibitory effect of combined tamoxifen (TAM) plus $\beta$-estradiol (E2) treatment on human DLD-1 CRC cells. The human DLD-1 CRC cell line was treated with different concentrations of TAM, $\beta$-estradiol, or a combination of these two agents. Cell viability was assessed using an MTT assay, while apoptosis was detected using flow cytometry analysis. Alterations in the RNA and protein levels of the apoptosis-associated factors cyclin D1 and survivin were measured in the treated DLD-1 cells using semi-quantitative polymerase chain reaction (sqPCR) and western blot analyses. Alterations in cellular migration ability were monitored using a Transwell migration assay. Treatment with TAM, $\beta$-estradiol and TAM plus $\beta$-estradiol inhibited DLD- 1 cell viability. The flow cytometry results revealed that these drugs promoted cell apoptosis, and the Transwell migration assay results indicated that the reduction in cell migration was greater in the TAM+E2 treatment group when compared with each treatment alone. sqPCR and western blot analysis results demonstrated that
\end{abstract}

Correspondence to: Dr Yu-Jing Fang or Professor De-Sen Wan, Department of Colorectal Surgery, Sun Yat-sen University Cancer Center, State Key Laboratory of Oncology in South China, Collaborative Innovation Center for Cancer Medicine, 651 Dongfeng Road East, Guangzhou, Guangdong 510060, P.R. China

E-mail: fangyj@sysucc.org.cn

E-mail: wands@sysucc.org.cn

*Contributed equally

Abbreviations: CRC, colorectal cancer; TAM, tamoxifen; ER, estrogen receptor; E2, 17 $\beta$-estradiol; DEPC, diethyl pyrocarbonate

Key words: colorectal cancer, endocrine therapy, tamoxifen, phenyl tetrazosurvivin, cyclin D1
TAM, E2 and a combination of the two affected survivin expression based on the drug concentration and the treatment duration; however, they demonstrated no significant effect on cyclin D1 expression. In conclusion, treatment of DLD-1 cells with TAM, $\beta$-estradiol, or a combination of these two drugs, inhibited cell viability and migration, promoted cell apoptosis, and reduced the mRNA and protein expression levels of survivin in a dose- and time-dependent manner. These results provide novel experimental basis for hormonal adjuvant therapy for the treatment of CRC.

\section{Introduction}

Colorectal cancer (CRC) is one of the most common malignant digestive tumors in China. In recent years, the global incidence of CRC has increased by $2 \%$ every year, while the incidence rate in China has increased by $4.2 \%$ each year $(1,2)$. As patients are more likely to be asymptomatic during the early stages of the disease, the majority of patients are already at advanced stages at the time of diagnosis. Therefore, their prognosis is poor and risk of mortality is higher (3). The comprehensive treatment for CRC primarily involves surgical resection combined with a variety of therapeutic measures, such as chemotherapy and radiotherapy. Chemotherapy remains one of the most essential approaches to CRC treatment. However, although chemotherapeutic drugs, including irinotecan, oxaliplatin and fluoropyrimidines, increase the efficacy of advanced CRC treatment, the median survival time of patients remains $<2$ years (4). Therefore, investigating novel and effective strategies to treat CRC is particularly important.

During the 1960s, Elwood V. Jensen and colleagues were the first to experimentally confirm the existence of the estrogen receptor (ER) (5). In the early 1970s, physicians began to use the ER as an indicator for the use of endocrine therapy in patients with breast cancer (6). The efficacy of endocrine therapy for ER-positive cancers was greater than that for ER-negative cancers. Starting in the mid-1970s, the ER was used as a prognostic indicator for patients with breast cancer, and gradually became the most effective therapeutic target (7). In 1997, investigators discovered a novel ER, known 
as $\operatorname{ER} \beta(8,9)$. The distribution of this receptor is different to that of the classic ER $\alpha$. In addition, this receptor demonstrates different specificities and affinities for ligands. ER $\beta$ is highly expressed in the gonads, uterus, colon and brain (10-12); however, its function in cancer has not yet been fully elucidated $(13,14)$. Similar to breast cancer, previous studies have demonstrated that CRC is a hormone-dependent cancer. The majority of CRC tissues and cell lines do not express ER $\alpha$, whereas they do express ER $\beta$ to a high level $(15,16)$. Using the semi-quantitative polymerase chain reaction (sqPCR) method, Arai et al (16) demonstrated that five human CRC cell lines expressed ER $\beta$ and not ER $\alpha$. As an anticancer hormonal therapy, tamoxifen (TAM) has been applied in hormone therapies targeting breast cancer. TAM is a chemically synthesized, nonsteroidal, anti-estrogen, antitumor drug. The precise mechanisms underlying the anticancer effects of TAM are currently unclear. TAM may compete with the intracellular ER to inhibit estradiol absorption in the body, thus inhibiting estrogen-dependent cancer growth (17). The main member of the estrogen family, 17 $\beta$-estradiol (E2), is a corticosteroid hormone that is primarily synthesized by ovarian follicles, the corpus luteum and the placenta during pregnancy (18). Epidemiological studies have demonstrated that the incidence of CRC in females is lower than that in males $(19,20)$, and additional studies have indicated that patients undergoing hormone replacement therapy, usually in the form of estrogen supplements, were less prone to suffer from CRC $(21,22)$. Therefore, the aim of the present study was to investigate the anticancer effects of combined TAM and E2 treatment on human DLD-1 CRC cells, in order to provide a theoretical and experimental basis for the clinical treatment of CRC using these agents.

\section{Materials and methods}

Cell culture. DLD-1 cells (Sun Yat-sen University Cancer Centre, Guangdong, China) were cultured in RPMI-1640 medium (Gibco; Thermo Fisher Scientific, Inc., Waltham, MA, USA) containing 10\% fetal bovine serum (FBS; Hyclone; GE Healthcare Life Sciences, Logan, UT, USA), 100 units/ml penicillin and $100 \mathrm{mg} / \mathrm{ml}$ streptomycin (both Gibco; Thermo Fisher Scientific, Inc.). Cells were maintained at $37^{\circ} \mathrm{C}$ in a humidified atmosphere containing $5 \% \mathrm{CO}_{2}$.

Effects of TAM and/or E2 on cell growth. DLD-1 cells were dissociated with trypsin and were re-suspended in culture medium containing $10 \% \mathrm{FBS}$ to produce a single-cell suspension. The cells were seeded onto 96 -well plates at $5 \times 10^{3}$ cells/well with $100 \mu \mathrm{l}$ in each well. Following incubation at $37^{\circ} \mathrm{C}$ in $5 \% \mathrm{CO}_{2}$ for $24 \mathrm{~h}$, the cells were treated with varying concentrations of the drugs. The concentrations applied in the group treated with E2 (Sigma-Aldrich; Merck KGaA, Darmstadt, Germany) only were $0.015625 \times 10^{-3}, 0.03125 \times 10^{-3}$, $0.0625 \times 10^{-3}, 0.125 \times 10^{-3}, 0.25 \times 10^{-3}, 0.5 \times 10^{-3}$ and $1 \times 10^{-3} \mathrm{M}$. The concentrations applied in the group treated with TAM (Yangtze River Pharmaceutical Group Co., Ltd., Taizhou, Jiangsu, China) only were $0.015625 \times 10^{-4}, 0.03125 \times 10^{-4}$, $0.0625 \times 10^{-4}, 0.125 \times 10^{-4}, 0.25 \times 10^{-4}, 0.5 \times 10^{-4}$ and $1 \times 10^{-4} \mathrm{M}$. The concentrations in the combined-treatment group were those of the lowest to highest corresponding concentrations in the TAM and E2 groups combined. Each well was treated with
$100 \mu \mathrm{l}$ of drug. The blank control group was treated with dimethyl sulfoxide (DMSO). A total of three replicates for each treatment were included. Following incubation for 24, 48 and 72 h, 0.05\% MTT (Guangzhou Whiga Technology Co., Ltd., Guangzhou, Guangdong, China; $20 \mu \mathrm{l} /$ well) was added, and the cells were incubated for a further $4 \mathrm{~h}$ at $37^{\circ} \mathrm{C}$. The supernatant was then discarded and $150 \mu \mathrm{l}$ of DMSO was added to each well. Following vigorous mixing for $10 \mathrm{~min}$, the absorbance of each well was measured at wavelengths of 490 and $655 \mathrm{~nm}$ using a microplate reader. The rate of cell viability inhibition was then calculated using the following equation based on optical density (OD): $1-\left[\mathrm{OD}_{\text {treatment group }} / \mathrm{OD}_{\text {control group }}\right]$.

Detection of cell apoptosis by flow cytometry analysis. DLD-1 cells $\left(\sim 5 \times 10^{5}\right)$ were seeded onto 60 -mm tissue culture plates and cultured for $24 \mathrm{~h}$. The culture medium was then discarded and fresh culture medium containing TAM or E2 was added. DMSO was used as a control. The experimental design was based on the MTT assay results. The concentration of drug that exhibited a $30 \%$ reduction in cell viability $\left(\mathrm{IC}_{30}\right)$, which demonstrated a relatively low inhibitory effect, and the $\mathrm{IC}_{70}$, which demonstrated a greater inhibitory effect, were used as a basis for grouping. Cells were treated with the following: DMSO (control); $0.0625 \times 10^{-3} \mathrm{M} \mathrm{E} 2 ; 0.5 \times 10^{-3} \mathrm{M}$ E2; $0.0625 \times 10^{-4} \mathrm{M}$ TAM; $0.25 \times 10^{-4} \mathrm{M}$ TAM; $0.0625 \times 10^{-3} \mathrm{M}$ $\mathrm{E} 2+0.0625 \times 10^{-4} \mathrm{M}$ TAM; $0.5 \times 10^{-3} \mathrm{M}$ E2 $+0.25 \times 10^{-4} \mathrm{M}$ TAM. The cells were cultured for 24,48 or $72 \mathrm{~h}$, then the supernatant was collected and adherent cells were dissociated with trypsin by centrifuging at $500 \mathrm{x} \mathrm{g}$ for $5 \mathrm{~min}$ and $4^{\circ} \mathrm{C}$ for downstream analysis. The cells were then washed with phosphate-buffered saline (PBS), centrifuged again at $500 \mathrm{x}$ g for $5 \mathrm{~min}$ and $4^{\circ} \mathrm{C}$ and double-stained using the Annexin-V-FLUOS Staining kit (Roche Diagnostics GmbH, Mannheim, Germany) according to the manufacturer's instructions in the dark for $5 \mathrm{~min}$. Apoptosis of the cells was measured using a flow cytometry instrument (Beckman Coulter, Inc., Brea, CA, US).

sqPCR analysis. DLD-1 cells $\left(\sim 2.5 \times 10^{-5}\right)$ were seeded onto 6 -well plates and incubated for $24 \mathrm{~h}$ for complete attachment. Cells were then treated with E2 and TAM, and total cellular RNA was extracted using TRIzol ${ }^{\circledR}$ reagent (cat. no. 15596; Invitrogen; Thermo Fisher Scientific, Inc.) according to the manufacturer's instructions. Total RNA was reverse transcribed using the RevertAid First Strand cDNA Synthesis kit and DreamTaq DNA Polymerase (both Fermentas; Thermo Fisher Scientific, Inc., Pittsburgh, PA, USA) according to the manufacturer's instructions. Reverse transcription of RNA was first performed using $1 \mu \mathrm{g}$ total RNA, $1 \mu \mathrm{l}$ random primers and diethyl pyrocarbonate (DEPC)-treated water to a final volume of $12 \mu \mathrm{l}$. Following incubation at $65^{\circ} \mathrm{C}$ for $5 \mathrm{~min}, 4 \mu \mathrm{l}$ Reaction Buffer (5X), 200 units Ribolock RNase inhibitor, 2 mM dNTP Mix and 200 units Revert Aid Moloney murine leukemia virus reverse transcriptase were added. Samples $(20 \mu \mathrm{l})$ was mixed gently and centrifuged at $500 \mathrm{x} \mathrm{g}$ for $5 \mathrm{~min}$ and $4^{\circ} \mathrm{C}$. The RT reaction conditions were as follows: $25^{\circ} \mathrm{C}$ for $5 \mathrm{~min}, 42^{\circ} \mathrm{C}$ for $60 \mathrm{~min}$, and reaction termination at $70^{\circ} \mathrm{C}$ for $5 \mathrm{~min}$. For amplification of cyclin D1, survivin and $\beta$-actin (the internal control) cDNA sequences, a PCR reaction mixture containing $2 \mu$ l DreamTaq Buffer (10X), $0.2 \mathrm{mM}$ dNTP Mix, $0.05 \mu \mathrm{M}$ primers, $1 \mu \mathrm{l}$ cDNA, $0.2 \mu \mathrm{l}$ DreamTaq DNA Polymerase 
and $13.8 \mu 1$ DEPC-treated water to a final volume of $20 \mu 1$ was used. PCR was performed in a S1000 Thermal Cycler (Bio-Rad Laboratories, Inc., Hercules, CA, USA). The reaction mixture was first heated to $95^{\circ} \mathrm{C}$ for $5 \mathrm{~min}$, then amplification was performed for 25 cycles of denaturation at $94^{\circ} \mathrm{C}$ for $30 \mathrm{sec}$, annealing at $60^{\circ} \mathrm{C}$ for $30 \mathrm{sec}$ and extension at $72^{\circ} \mathrm{C}$ for $30 \mathrm{sec}$, which was followed by a final extension step at $72^{\circ} \mathrm{C}$ for $7 \mathrm{~min}$. The primer sequences were as follows: Cyclin D1, forward, 5'-GTCACCTAGCAAGCTGCCGAACC-3', and reverse, 5'-ACGACAGACAAAGCGTCCCTCAA-3'; survivin, forward, 5'-TCTGGCGTAAGATGATGG-3', and reverse, 5'-GAAATAAGTGGGTCTGAAGTG-3'; $\beta$-actin, forward, 5'-TTAGTTGCGTTACACCCTTTC-3', and reverse, 5'-AAC CGACTGCTGTCACCTTC-3'. The PCR products were separated on a $2 \%$ agarose gel and visualized using $1 \%$ ethidium bromide staining and ultraviolet illumination. The expected sizes of the amplification products were 222 bp for cyclin D1, $363 \mathrm{bp}$ for survivin and $164 \mathrm{bp}$ for $\beta$-actin. Target gene expression levels were semi-quantified based on band intensities using the Bio-Rad GelDoc XR instrument and Quantify One software version 4.6.9 (both Bio-Rad Laboratories, Inc.). The following equations were used: Band Intensity = mean OD $x$ band area; and Relative Quantification of mRNA = band intensity target gene /band intensity internal reference.

Western blot analysis. DLD-1 cells $\left(\sim 1 \times 10^{6}\right)$ were seeded onto $100-\mathrm{mm}^{2}$ tissue culture plates and incubated for $24 \mathrm{~h}$ for complete attachment. The cells were treated according to the aforementioned experimental groupings and were harvested following dissociation with trypsin. Cells were washed twice with PBS, centrifuged at $500 \mathrm{x}$ g for $5 \mathrm{~min}$ and $4^{\circ} \mathrm{C}$, and $60 \mu 1$ ProteoJET Mammalian Cell Lysis Reagent (Fermentas; Thermo Fisher Scientific, Inc.) was added. The cells were vortexed for $10 \mathrm{sec}$ and lysed for $30 \mathrm{~min}$ with occasional vortexing. Following centrifugation at $16,000 \mathrm{x} g$ for $30 \mathrm{~min}$ and $4^{\circ} \mathrm{C}$, the supernatant was transferred to a fresh Eppendorf tube and stored at $-80^{\circ} \mathrm{C}$. The protein concentration was determined using a Pierce BCA Protein assay kit (Thermo Fisher Scientific, Inc.) according to the manufacturer's instructions. Equal quantities of protein $(20 \mu \mathrm{g})$ were loaded and separated by $10 \%$ SDS-PAGE. The proteins were then electrotransferred onto a polyvinylidene fluoride membrane. The membrane was blocked with Tris-buffered saline solution containing 1\% Tween-20 (TBS-T) buffer and $5 \%$ skim milk for $1 \mathrm{~h}$ at room temperature, followed by incubation with the following primary antibodies at $4^{\circ} \mathrm{C}$ overnight: Anti-cyclin D1 (cat. no. 2926; dilution, 1:1,000; CST Biological Reagents Company Limited, Shanghai, China), anti-survivin (cat. no. ab8228; dilution, 1:1,000; Abcam, Cambridge, UK) and anti- $\beta$-actin (cat. no. ms-1295; dilution, 1:5,000; Thermo Fisher Scientific, Inc.). The membrane was then washed using TBS-T and incubated with secondary antibodies [Amersham ECL sheep anti-mouse IgG, horseradish peroxidase (HRP)-linked whole Ab; cat. no. NA931; dilution, 1:5,000; GE Healthcare Bio-Sciences, Pittsburgh, PA, USA; and the Amersham ECL donkey anti-rabbit IgG, HRP-linked whole Ab; cat. no. NA934; dilution, 1:5,000; GE Healthcare Bio-Sciences] at room temperature for $1 \mathrm{~h}$. The membrane was subsequently washed three times with TBS-T, and proteins were detected using an enhanced chemiluminescence reagent kit (cat. no. WBKLS0100; EMD Millipore, Billerica, MA, US) according to the manufacturer's instructions. Then the membrane was exposed using X-ray film in a dark room. The $\mathrm{X}$-ray film was scanned, and protein expression was quantified by densitometric analysis using Image J v1.46r software (National Institutes of Health, Bethesda, MD, USA). Three experimental repeats were performed.

Detection of cell migration ability using the Transwell assay. Cells were treated for $24 \mathrm{~h}$ according to the aforementioned experimental groupings. The cells were then dissociated with trypsin, harvested, and counted. The upper chambers of the Transwell plates (Corning Incorporated, Corning, NY, USA) containing an $8.0-\mu \mathrm{m}$ membrane, were seeded with $5 \times 10^{5}$ cells. Complete medium containing $20 \%$ FBS was then added to the lower chambers, and the Transwell plates were placed in an incubator at $37^{\circ} \mathrm{C}$ for $24 \mathrm{~h}$. Non-migrated cells in the upper chamber were then removed with a cotton swab. Following washing twice with PBS, the cells were fixed with $75 \%$ ethanol for $20 \mathrm{~min}$ at room temperature, stained with $10 \%$ Giemsa stain for $10 \mathrm{~min}$ at room temperature, washed with running water, dried and cells in ten random high-magnification fields of view were counted under a light microscope. The average number of migrated cells in each group was then calculated.

Statistical analysis. Data were presented as a percentage or the mean. Statistical analyses were performed using SPSS software (version 21.0; IBM SPSS, Armonk, NY, USA). Group comparisons of normally distributed data were performed using Student's t-tests (for two samples) or one-way analysis of variance (for multiple comparisons using a Bonferroni post hoc test). All statistical tests used in this study were two-sided, and $\mathrm{P}<0.05$ was considered to indicate a statistically significant difference.

\section{Results}

The inhibitory effects of TAM and E2 on the viability of DLD-1 CRC cells. As shown in Fig. 1A, the rate of inhibition of DLD-1 cell viability was positively associated with TAM concentration following $24 \mathrm{~h}(\mathrm{P}=0.018), 48 \mathrm{~h}(\mathrm{P}=0.016)$ and $72 \mathrm{~h}(\mathrm{P}=0.017)$ of treatment. The rate of inhibition of DLD-1 cell viability was also positively associated with $\mathrm{E} 2$ concentration following $24 \mathrm{~h}(\mathrm{P}=0.024), 48 \mathrm{~h}(\mathrm{P}=0.028)$ and $72 \mathrm{~h}(\mathrm{P}=0.021)$ of treatment (Fig. 1B). In addition, as shown in Fig. 1C, the rate of inhibition of DLD-1 cell viability was positively associated with the concentration of combination-treatment (TAM+E2) following $24 \mathrm{~h}(\mathrm{P}=0.018), 48 \mathrm{~h}(\mathrm{P}=0.021)$ and $72 \mathrm{~h}(\mathrm{P}=0.028)$ of treatment. The $\mathrm{IC}_{50}$ values for TAM, E2 and combined drug treatment (TAM+E2) for 24, 48 and $72 \mathrm{~h}$ were decreased, respectively (Fig. 1D). Furthermore, the combination-treatment group exhibited the greatest reduction in DLD-1 cell viability when compared with the single-drug-treatment groups $(\mathrm{P}<0.05)$. In addition, TAM treatment alone reduced the viability of DLD-1 cells to a greater extent than E2 treatment alone $(\mathrm{P}<0.05$; Fig. 1D).

Induction of DLD-1 cell apoptosis by TAM and E2. The results of the quantitative annexin-V/propidium iodide double-staining assay revealed that TAM, E2 and TAM+E2 
A

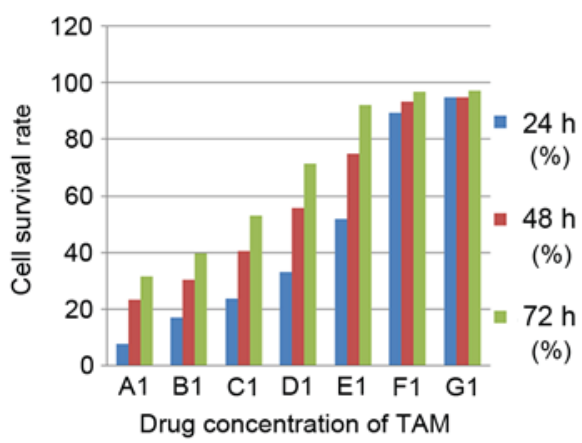

C

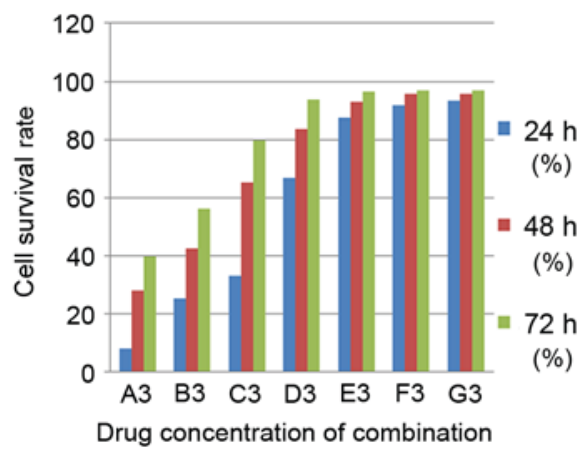

B

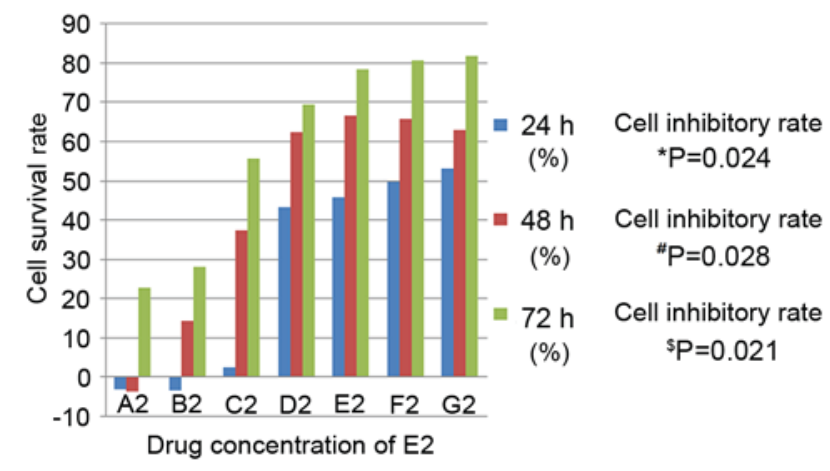

D
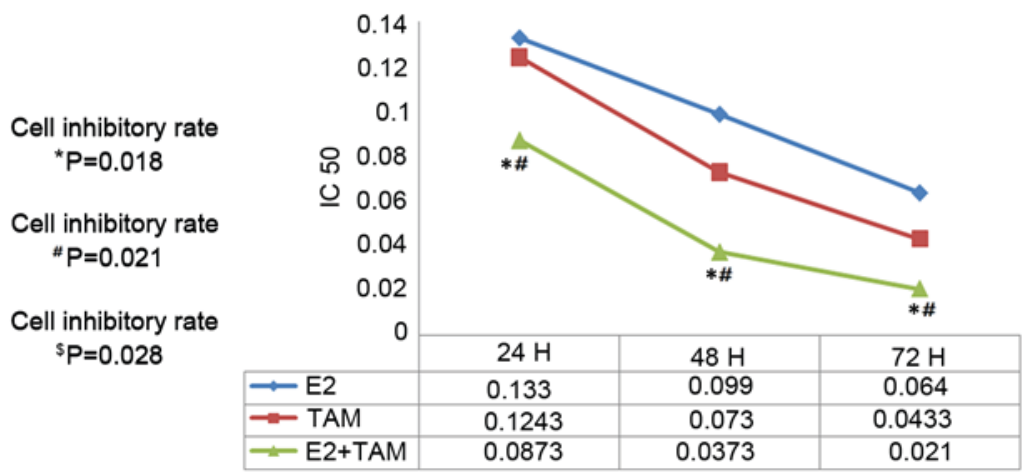

Figure 1. Inhibitory effects of TAM, E2 or TAM plus E2 treatment on cell viability, as determined using an MTT assay. (A) TAM only treatment: A1, $0.015625 \times 10^{-4} \mathrm{M} ; \mathrm{B} 1,0.03125 \times 10^{-4} \mathrm{M} ; \mathrm{C} 1,0.0625 \times 10^{-4} \mathrm{M} ; \mathrm{D} 1,0.125 \times 10^{-4} \mathrm{M} ; \mathrm{E} 1,0.25 \times 10^{-4} \mathrm{M} ; \mathrm{F} 1,0.5 \times 10^{-4} \mathrm{M} ; \mathrm{G} 1,1 \times 10^{-4} \mathrm{M}$. The effect of cell viability inhibition was positively associated with TAM concentration $\left({ }^{*} \mathrm{P}<0.05\right.$ at $24 \mathrm{~h} ;{ }^{\prime} \mathrm{P}<0.05$ at $48 \mathrm{~h} ;{ }^{\circ} \mathrm{P}<0.05$ at $72 \mathrm{~h}$; comparisons were made between all concentrations at each time point). (B) E2 only treatment: A2, $0.015625 \times 10^{-3} \mathrm{M} ; \mathrm{B} 2,0.03125 \times 10^{-3} \mathrm{M} ; \mathrm{C} 2,0.0625 \times 10^{-3} \mathrm{M} ; \mathrm{D} 2,0.125 \times 10^{-3} \mathrm{M} ; \mathrm{E} 2,0.25 \times 10^{-3} \mathrm{M} ; \mathrm{F} 2,0.5 \times 10^{-3} \mathrm{M} ; \mathrm{G} 2$, $1 \times 10^{-3} \mathrm{M}$. The effect of cell viability inhibition was positively associated with $\mathrm{E} 2$ concentration $\left({ }^{*} \mathrm{P}<0.05\right.$ at $24 \mathrm{~h} ;{ }^{*} \mathrm{P}<0.05$ at $48 \mathrm{~h} ;{ }^{\mathrm{S}} \mathrm{P}<0.05$ at $72 \mathrm{~h} ;$ comparisons were made between all concentrations at each time point). (C) Combination-treatment group: A3, A1+A2; B3, B1+B2; C3, C1+C2; D3, D1+D2; E3, E1+E2; $\mathrm{F} 3, \mathrm{~F} 1+\mathrm{F} 2 ; \mathrm{G} 3, \mathrm{G} 1+\mathrm{G} 2$. The effect of cell viability inhibition was positively associated with combination-treatment concentration $\left({ }^{*} \mathrm{P}<0.05\right.$ at $24 \mathrm{~h} ;{ }^{\prime \prime} \mathrm{P}<0.05$ at $48 \mathrm{~h} ;{ }^{\$} \mathrm{P}<0.05$ at $72 \mathrm{~h}$; comparisons were made between all concentrations at each time point). (D) $\mathrm{The} \mathrm{IC}_{50}$ results of the three treatments were determined using an MTT assay. The $\mathrm{IC}_{50}$ results indicate that the inhibitory effects in these three treatment groups increased with an increase in treatment duration. The combination-treatment group exhibited the highest rate of inhibition. "P<0.05 vs. TAM; " $\mathrm{P}<0.05$ vs. E2. TAM, tamoxifen; E2, 17AM, tamoxifen; IC ${ }_{50}$, half maximal inhibitory concentration.

significantly induced DLD-1 cell apoptosis when compared to the control group (TAM: $\mathrm{P}<0.05$; $\mathrm{E} 2$ : $\mathrm{P}<0.05$; TAM+E2: $\mathrm{P}<0.05)$. In addition, apoptosis rates were positively associated with the treatment duration and drug concentration (Fig. 2A). The rate of apoptosis was low following treatment with TAM and E2 for $24 \mathrm{~h}$, while the rate of apoptosis in the drug-combination treatment group reached $15 \%$ following $24 \mathrm{~h}$ (Fig. 2A). Following $48 \mathrm{~h}$ of treatment, the TAM and E2-treated groups exhibited increased apoptosis. The rate of apoptosis in $0.5 \times 10^{-3}$ M E2-treated cells was $23.1 \%$, and in $0.25 \times 10^{-4} \mathrm{M}$ TAM-treated cells the apoptosis rate was $22 \%$ (Fig. 2). The rate of apoptosis increased following $72 \mathrm{~h}$, whereby $0.0625 \times 10^{-3} \mathrm{M}$ E2 and $0.5 \times 10^{-3} \mathrm{M}$ E2-treated groups demonstrated apoptosis rates of 34.7 and $51.6 \%$, respectively, and the rates of apoptosis for the $0.0625 \times 10^{-4} \mathrm{M}$ TAM and $0.25 \times 10^{-4} \mathrm{M}$ TAM-treated groups were 16.4 and $54.9 \%$, respectively. In addition, the rate of apoptosis for the drug-combination treatment group reached $32.3 \%$ following $72 \mathrm{~h}$ (Fig. 2A).

Effects of TAM and E2 on survivin and cyclin D1 mRNA expression as determined by sqPCR. DLD-1 cells were treated with $0.015625 \times 10^{-4}, 0.03125 \times 10^{-4}, 0.0625 \times 10^{-4}$ and $0.125 \times 10^{-4}$ M TAM, $0.015625 \times 10^{-3}, 0.03125 \times 10^{-3}, 0.0625 \times 10^{-3}, 0.125 \times 10^{-3}$,
$0.25 \times 10^{-3}, 0.5 \times 10^{-3}$ and $1 \times 10^{-3} \mathrm{M} \mathrm{E} 2$, or a combination of these two drugs for 24,48 and $72 \mathrm{~h}$. The results indicated that the cyclin D1 mRNA expression levels were not significantly altered, while the expression of survivin mRNA was decreased; the degree of which was positively associated with drug concentration and treatment duration. The combined treatment markedly decreased the expression of survivin mRNA when compared with each treatment alone (Fig. 3).

Effect of TAM and E2 on survivin and cyclin D1 protein expression levels in DLD-1 cells as determined by western blot analysis. Following treatment of DLD-1 cells with $0.015625 \times 10^{-4}, 0.03125 \times 10^{-4}, 0.0625 \times 10^{-4}$ and $0.125 \times 10^{-4} \mathrm{M}$ TAM for 24,48 or $72 \mathrm{~h}$, the level of cyclin D1 protein expression was not significantly altered, while survivin protein expression levels were decreased; the degree of which was positively associated with drug concentration and treatment duration (Fig. 4A). Following treatment with $0.015625 \times 10^{-3}$, $0.03125 \times 10^{-3}, 0.0625 \times 10^{-3}, 0.125 \times 10^{-3}, 0.25 \times 10^{-3}, 0.5 \times 10^{-3}$ and $1 \times 10^{-3} \mathrm{M}$ E2, the level of cyclin D1 protein expression was not significantly altered. In addition, the level of survivin protein expression was not significantly altered following $24 \mathrm{~h}$ of E2 treatment, however, it was observed to increase with increasing 
A

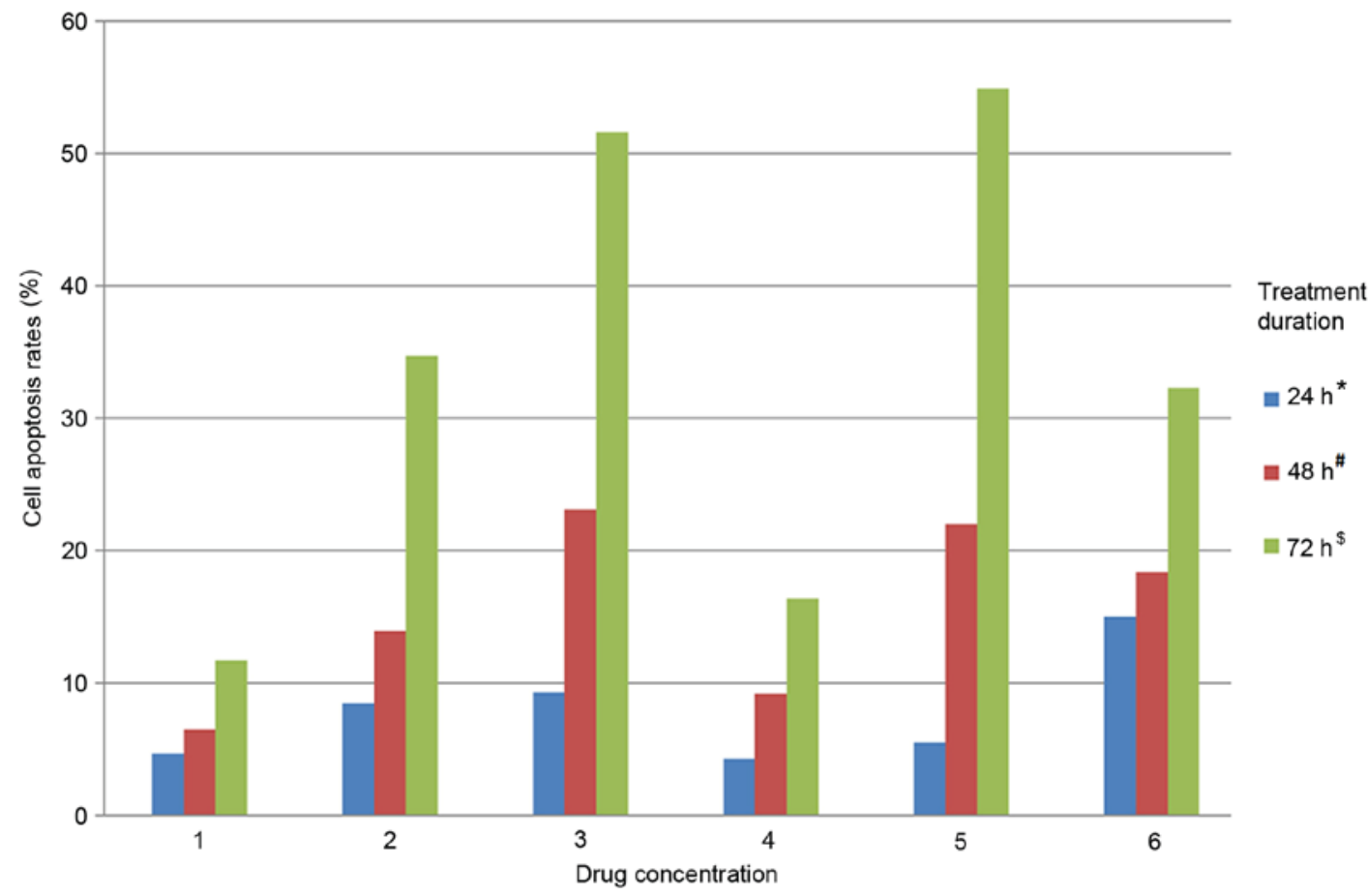

B
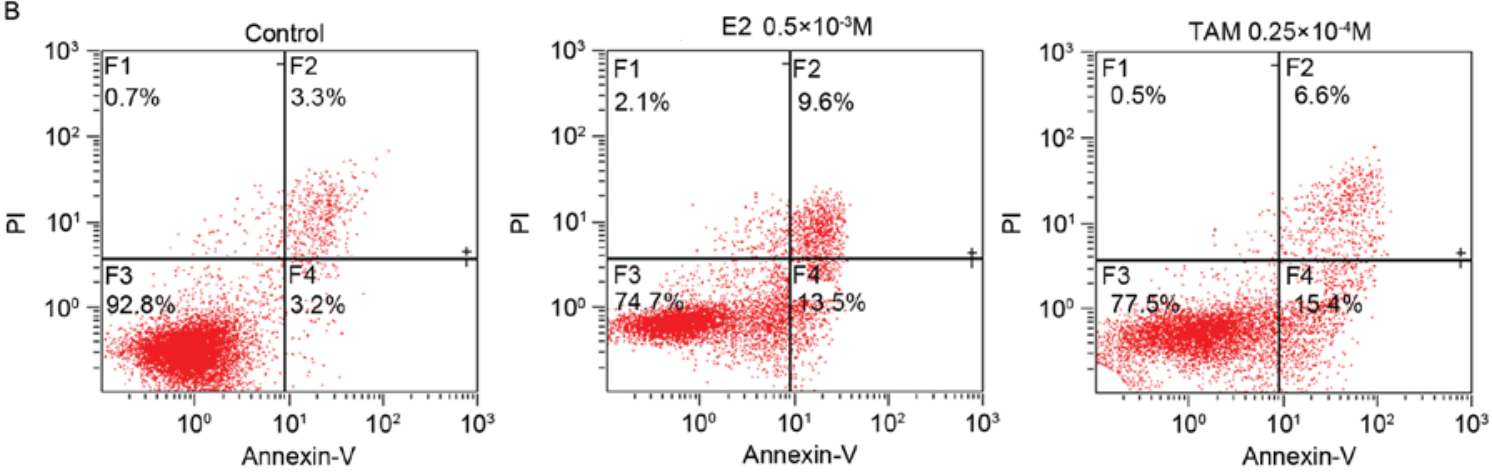

C
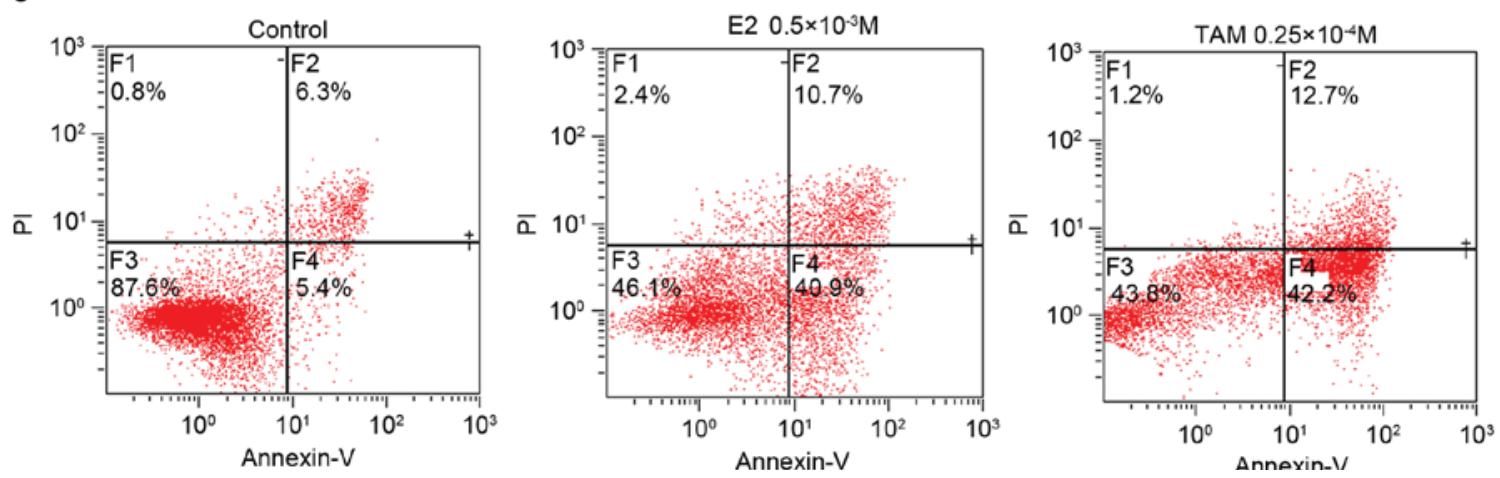

Figure 2. Induction of DLD-1 cell apoptosis by TAM and E2. (A) Cell apoptosis rates following treatment with TAM and/or E2. 1, control; 2, $0.0625 \times 10^{-3} \mathrm{M}$ E2; 3, $0.5 \times 10^{-3} \mathrm{M} \mathrm{E2} ; 4,0.0625 \times 10^{-4} \mathrm{M}$ TAM; $5,0.25 \times 10^{-4} \mathrm{M}$ TAM; $6,0.0625 \times 10^{-3} \mathrm{M}$ E2 $+0.0625 \times 10^{-4} \mathrm{M}$ TAM. With increasing concentrations of drug and treatment duration, the rate of apoptosis increased in $24 \mathrm{~h}\left({ }^{*} \mathrm{P}<0.05\right), 48 \mathrm{~h}\left({ }^{(} \mathrm{P}<0.05\right)$ and $72 \mathrm{~h}\left({ }^{\$} \mathrm{P}<0.05\right.$; comparisons were made between all concentrations at each time point). Following drug treatment for $72 \mathrm{~h}$, high concentrations of E2 and TAM effectively induced DLD-1 cell apoptosis, and the rate of apoptosis reached 51.6 and $54.9 \%$, respectively. (B) Apoptosis induced by $0.5 \times 10^{-3} \mathrm{M}$ E2 or $0.25 \times 10^{-4} \mathrm{M}$ TAM for $48 \mathrm{~h}$. (C) Apoptosis induced by $0.5 \times 10^{-3} \mathrm{M}$ E2 or $0.25 \times 10^{-4} \mathrm{M}$ TAM for $72 \mathrm{~h}$. TAM, tamoxifen; E2, $17 \beta$-estradiol; PI, propidium iodide.

drug concentrations at 48 and $72 \mathrm{~h}$ of treatment (Fig. 4B). Higher levels of survivin protein expression were observed at high and low drug concentrations, and lower levels of expression were observed at medium drug concentrations (Fig. 4B).
In the combination-drug treatment group, the level of cyclin D1 protein expression was not significantly altered, while expression of the survivin protein decreased in a concentration and time-dependent manner (Fig. 4C). 


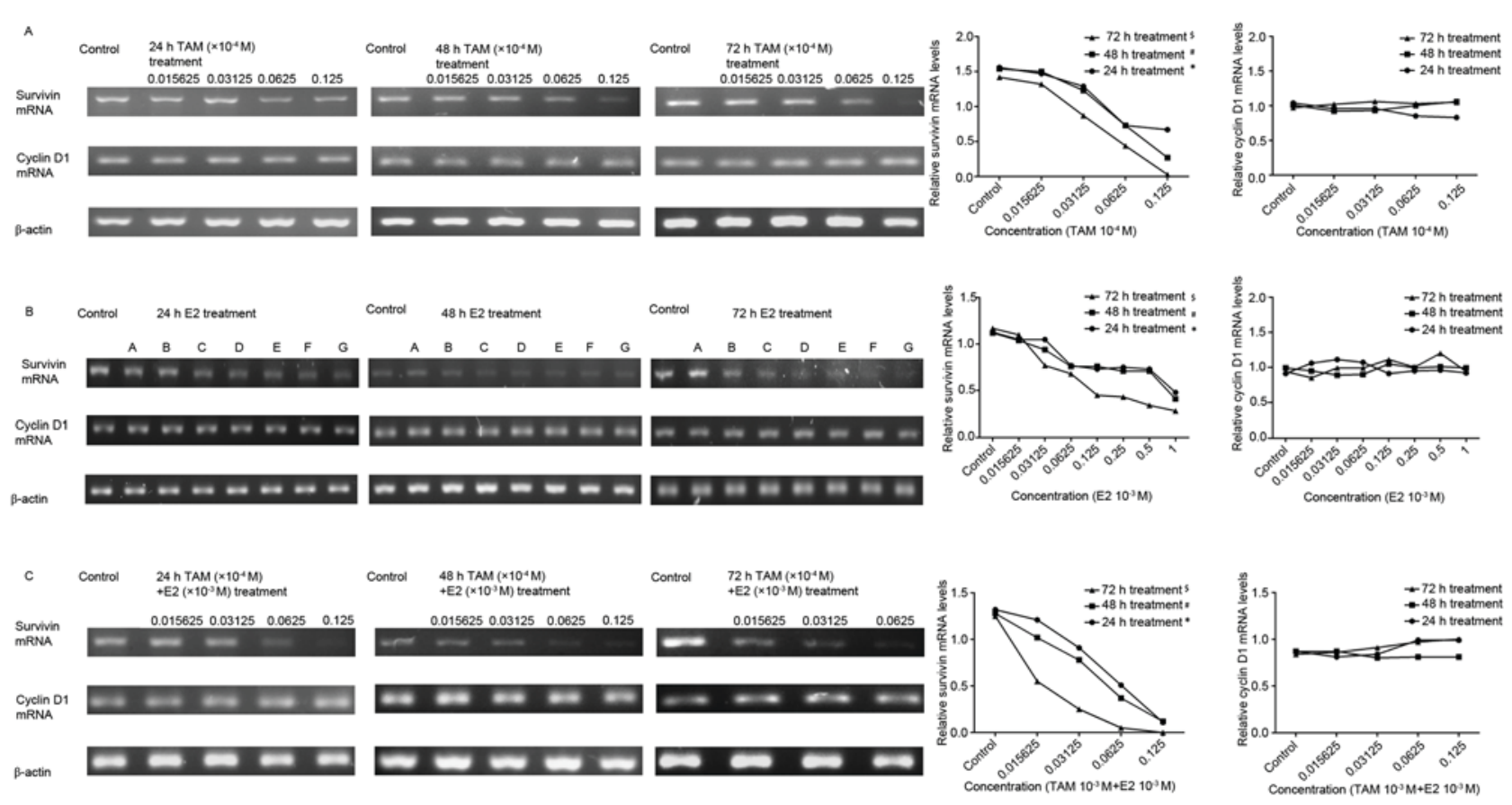

Figure 3. Effect of TAM and/or E2 treatment on survivin and cyclin D1 mRNA expression levels, as determined by sqPCR analysis. Gray-scale band densities of the reverse transcription-polymerase chain reaction results in each treatment group were compared and analyzed using ImageJ software. (A) Following treatment of DLD-1 cells with TAM, cyclin D1 mRNA expression levels were not significantly altered, while relative survivin mRNA expression levels were significantly decreased following treatment with increasing concentrations of TAM at $24 \mathrm{~h}\left({ }^{*} \mathrm{P}<0.05\right), 48 \mathrm{~h}\left({ }^{*} \mathrm{P}<0.05\right)$ and $72 \mathrm{~h}\left({ }^{\$} \mathrm{P}<0.05\right.$; comparisons were made between all concentrations at each time point). (B) The expression of survivin and cyclin D1 following treatment of DLD-1 cells with E2. A, $0.015625 \times 10^{-3} \mathrm{M}$; $\mathrm{B}, 0.03125 \times 10^{-3} \mathrm{M} ; \mathrm{C}, 0.0625 \times 10^{-3} \mathrm{M} ; \mathrm{D}, 0.125 \times 10^{-3} \mathrm{M} ; \mathrm{E}, 0.25 \times 10^{-3} \mathrm{M} ; \mathrm{F}, 0.5 \times 10^{-3} \mathrm{M} ; \mathrm{G}, 1 \times 10^{-3} \mathrm{M}$. Following treatment, cyclin D1 mRNA expression levels were not significantly altered, while relative survivin mRNA expression levels were significantly decreased with increasing concentrations of $\mathrm{E} 2$ at $24 \mathrm{~h}\left({ }^{*} \mathrm{P}<0.05\right)$, $48 \mathrm{~h}\left({ }^{\sharp} \mathrm{P}<0.05\right)$ and $72 \mathrm{~h}\left({ }^{\$} \mathrm{P}<0.05\right.$; comparisons were made between all concentrations at each time point). (C) Expression of survivin and cyclin D1 following treatment of DLD-1 cells with TAM + E2. Cyclin D1 mRNA expression levels were not significantly altered, while relative survivin mRNA expression levels were significantly decreased with increasing drug concentrations at $24 \mathrm{~h}\left({ }^{*} \mathrm{P}<0.05\right), 48 \mathrm{~h}\left({ }^{*} \mathrm{P}<0.05\right)$ and $72 \mathrm{~h}\left({ }^{\$} \mathrm{P}<0.05\right.$; comparisons were made between all concentrations at each time point). The results are presented as the expression level of survivin relative to that of the $\beta$-actin internal control. TAM, tamoxifen; E2, 17ß-estradiol.

Effects of TAM and/or E2 treatment on the migration capability of DLD-1 cells. The results of the Transwell migration assay demonstrated that TAM and/or E2 treatment demonstrated significant inhibitory effects on the migration capabilities of DLD-1 cells (Fig. 5). DLD-1 cells were treated with $0.015625 \times 10^{-3}, 0.03125 \times 10^{-3}, 0.0625 \times 10^{-3}, 0.125 \times 10^{-3}$, $0.25 \times 10^{-3}, 0.5 \times 10^{-3}$ and $1 \times 10^{-3} \mathrm{M} \mathrm{E} 2$ and the average number of cells that traversed the membrane in ten random high magnification fields of view was 436 $\pm 11.1,330 \pm 9.7,226 \pm 8.4,154 \pm 3.9$, $54 \pm 3.1,36 \pm 2.3$ and $20 \pm 1.6$, respectively (Fig. 5A). Following treatment with $0.015625 \times 10^{-4}, 0.03125 \times 10^{-4}, 0.0625 \times 10^{-4}$, $0.125 \times 10^{-4}$ and $0.25 \times 10^{-4} \mathrm{M}$ TAM, the average numbers of cells that traversed the membrane were $217 \pm 9.5,215 \pm 8.2,200 \pm 7.6$, $65 \pm 3.4$ and $16 \pm 1.4$, respectively. Following TAM plus E2 treatment, the calculated average numbers of migrated cells were $225 \pm 7.0,165 \pm 5.5,106 \pm 5.1$ and $11 \pm 1.0$ at increasing concentrations, respectively (Fig. 5). Treatment with TAM, E2 and the combination-treatment significantly inhibited the migration capabilities of DLD-1 cells in a dose-dependent manner. The inhibitory effect of the combined treatment on cell migration was greater than each treatment alone $(\mathrm{P}<0.05$; Fig. 5).

\section{Discussion}

Previous studies have demonstrated that estrogen serves a role in the development of CRC $(23,24)$. The incidence rates of breast cancer are increased in postmenopausal women treated with hormone replacement therapy, while the incidence rate of CRC is significantly decreased $(25,26)$. The expression of the ER $\alpha$ subtype is low in the gastrointestinal tract and in gastrointestinal tract tumors. Therefore, it was hypothesized that the decreased incidence of CRC in these individuals may be associated with the ER $\beta$ subtype (27). Paruthiyil et al (28) demonstrated that E2 promoted the proliferation of ER $\alpha$-positive breast cancer cell lines, and inhibited the proliferation of ER $\beta$-positive breast cancer cell lines. Li et al (29) confirmed that low concentrations of E2 stimulated the proliferation of human colon carcinoma-derived caco- 2 cells, while Arai et al (16) revealed that estrogen did not affect the proliferation of five human CRC cell lines with ER $\beta$ expression and no ER $\alpha$ expression, however, estrogen did affect the proliferation of ER $\alpha$-expressing cell lines. Therefore, it was hypothesized that the expression of $E R \alpha$ is very important for the function of estrogen. However, it is possible that the expression levels of ER $\beta$ were low in these cell lines. Hendrickse et al (30) demonstrated that the level of the ER in HT-29, Colo320 and Lovo cells was lower than $12 \mathrm{fmol} / \mathrm{mg}$ protein, and the transcriptional activity of ER $\beta$ was lower than that of ER $\alpha$. Therefore, one of the aims of the present study was to determine the effect of different concentrations of estrogen on the viability of CRC cells. The present study used DLD-1 cells, which express the ER $\beta$ subtype only. The results revealed that a low concentration of E2 promoted DLD-1 cell viability following a short duration of treatment. With an increase in treatment duration 

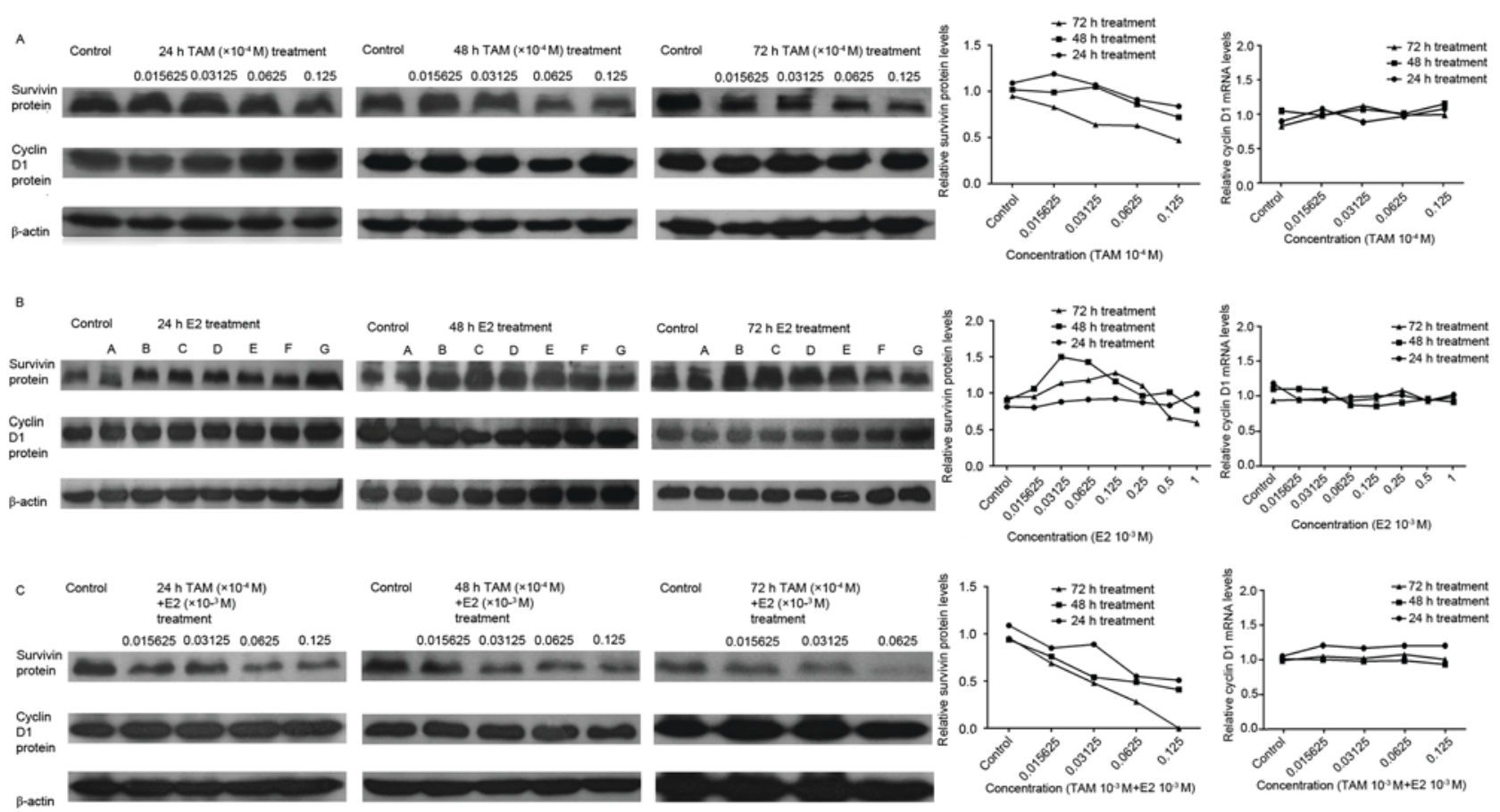

Figure 4. Effect of TAM and/or E2 treatment on survivin and cyclin D1 protein expression levels, as determined by western blotting. Gray-scale band densities were compared and analyzed using the ImageJ software. (A) DLD-1 cells following treatment with TAM. Cyclin D1 protein expression levels were not significantly altered, while relative survivin protein expression levels exhibited decreased with increasing drug concentrations. (B) DLD-1 cells following treatment with E2. A, $0.015625 \times 10^{-3} \mathrm{M} ; \mathrm{B}, 0.03125 \times 10^{-3} \mathrm{M}$; C, $0.0625 \times 10^{-3} \mathrm{M} ; \mathrm{D}, 0.125 \times 10^{-3} \mathrm{M}$; E, $0.25 \times 10^{-3} \mathrm{M} ; \mathrm{F}, 0.5 \times 10^{-3} \mathrm{M}$; G, $1 \times 10^{-3} \mathrm{M}$. Following treatment, cyclin $\mathrm{D} 1$ protein expression levels were not significantly altered. Survivin protein expression levels were not significantly altered following $24 \mathrm{~h}$ incubation, whereas treatment with $>0.03125 \times 10^{-3} \mathrm{M}$ E2 at $48 \mathrm{~h}$ and $>0.125 \times 10^{-3} \mathrm{M}$ E2 at $72 \mathrm{~h}$ was associated with a reduction in survivin protein expression levels. (C) DLD-1 cells following treatment with TAM + E2. Cyclin D1 protein expression levels were not significantly altered, while relative survivin protein expression levels decreased with increasing drug concentrations. Results are presented as the expression of survivin relative to the $\beta$-actin internal control. TAM, tamoxifen; E2, 17 $\beta$-estradiol.

and concentration, E2 exhibited inhibitory effects on DLD-1 cell viability. The authors hypothesize that this result may be associated with the lower transcriptional activity of the ER $\beta$ subtype following exposure to low concentrations of estrogen.

Fox et al (31) proposed that ER $\beta$ may be suitable as a therapeutic target for TAM as the affinity of ER $\beta$ for TAM is higher than for E2. In addition, Miller et al (32) observed that TAM treatment was associated with an increase in ER $\alpha$ and a decrease in ER $\beta$ expression. Arai et al (16) demonstrated that TAM inhibited the proliferation of MCF-7, HT-29 and Colo320 cells. The results of the present study indicated that TAM inhibited the viability of DLD-1 cells, and that this effect was positively associated with drug concentration and treatment duration. TAM belongs to a class of drugs known as selective ER modulators. TAM competes with estrogen for binding to the ER. However, the effects of TAM are complex $(33,34)$. Whether TAM activates or inhibits the ER following binding depends on the target tissue type. Krishnan et al (35) demonstrated that TAM binds to the ER $\beta$ subtype to effectively antagonize the function of estrogen and downregulate ER $\beta$ expression. In the present study, treatment with TAM plus E2 demonstrated inhibitory effects on the viability of DLD-1 cells. This effect was positively associated with the concentration of drug and duration of treatment, and was stronger than that of the single-drug treatments. These results indicate that the antiestrogenic function of TAM via binding to the ER $\beta$ may not be the only mechanism involved in the inhibition of cell proliferation by TAM.
The results of the present study demonstrated that TAM and E2 induce DLD-1 apoptosis. The apoptosis rate was positively associated with treatment duration and drug concentration. Induction of apoptosis following TAM plus E2 treatment was greater than that of the single-drug treatments. Therefore, TAM and E2 may demonstrate synergistic effects in the regulation of apoptosis. In previous breast cancer studies, Hou et al (36) revealed that ER $\beta$ promoted the development and metastasis of cancer. In the present study, the Transwell assay results indicated that TAM, E2 and the combined drug treatment demonstrated significant inhibitory effects on the migration capabilities of the DLD-1 cells. In addition, combined treatment had a greater effect on the cell migration capabilities of DLD-1 cells. Therefore, the authors speculated that TAM and E2 may exhibit synergistic effects in the downregulation of $\mathrm{ER} \beta$ expression, thereby inhibiting proliferation, infiltration to the surrounding tissues and distal metastasis of CRC.

Previous studies have demonstrated that CRC is associated with a variety of genes including k-ras, c-Myc, B-cell lymphoma-2, p53, survivin and cyclin D1 (37-41). Among these genes, survivin is a member of the inhibitors of apoptosis protein family. The survivin gene is localized on human chromosome 17q25 and is associated with the apoptosis and proliferation of cells. Downregulation of survivin demonstrates antitumor effects, which have a therapeutic value (42). Overexpression of cyclin D1, one of the cell cycle regulators, is a hallmark of a number of primary human tumors (43). Cyclin D1 expression is very important for the diagnosis and 
A

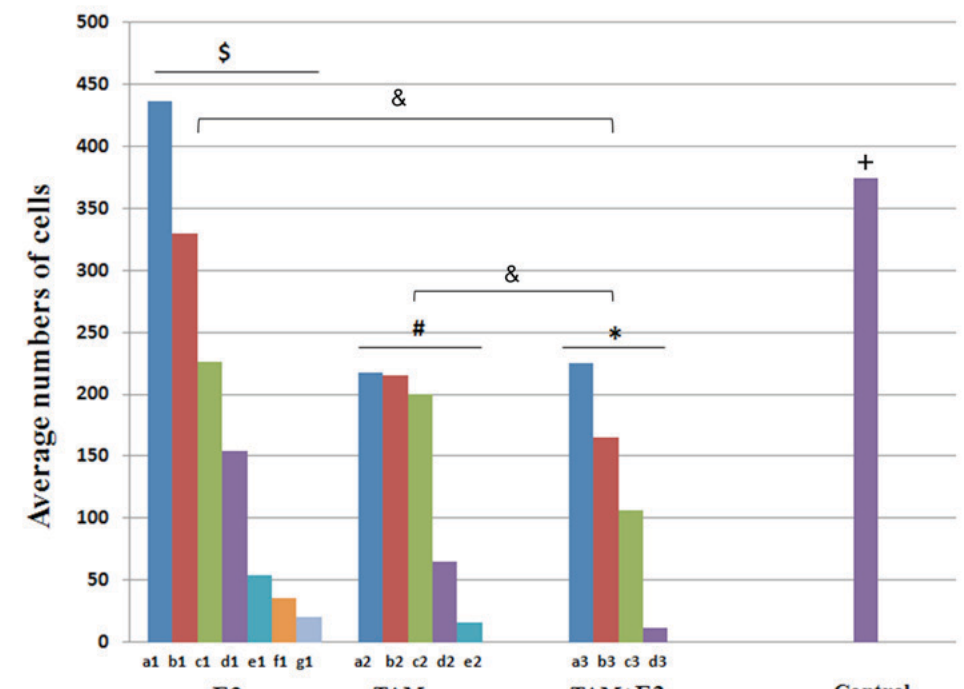

B E2 TAM TAM+E2

Control

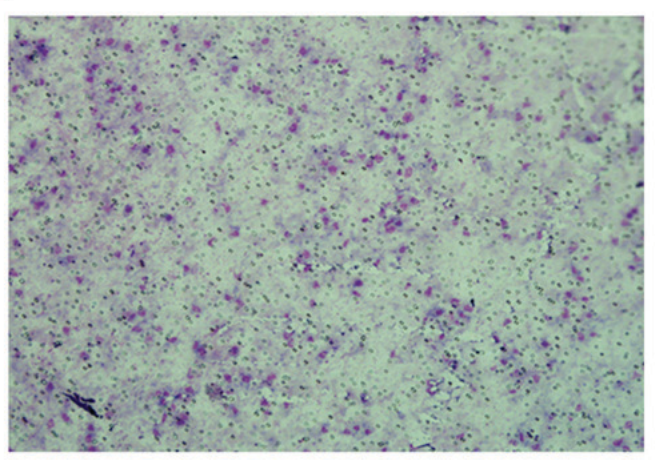

Control

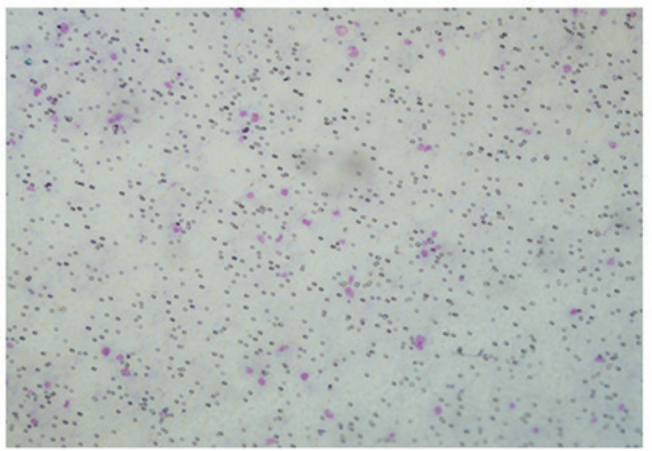

TAM $0.125 \times 10^{-4} M$

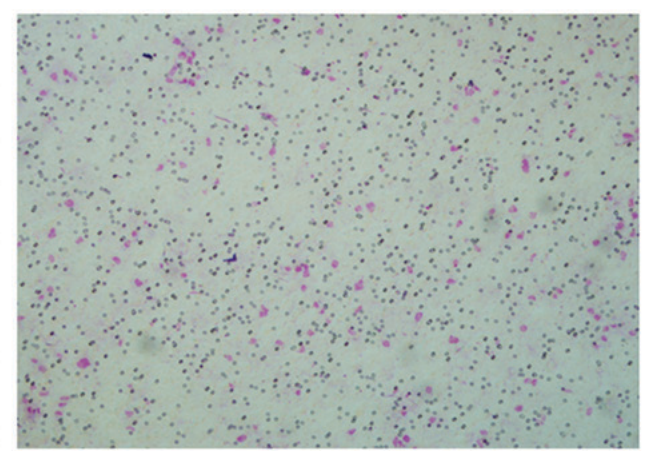

$\mathrm{E} 20.125 \times 10^{-3} \mathrm{M}$

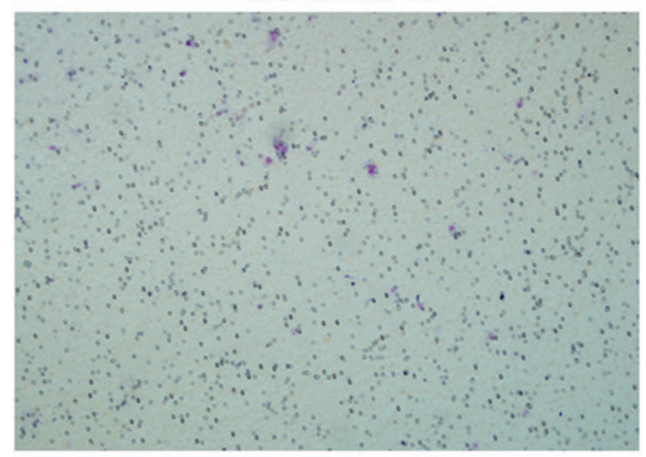

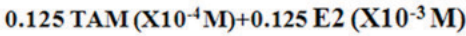

Figure 5. Effect of TAM and/or E2 treatment on the migration of DLD-1 cells. (A) The average numbers of cells that traversed the Transwell membrane in 10 high magnification fields of view selected at random. E2 significantly inhibited the migration capabilities of DLD-1 cells in a dose-dependent manner ( ${ }^{\$} \mathrm{P}<0.01$, comparisons were made between all concentrations in the E2 group); a1, $0.015625 \times 10^{-4} \mathrm{M} \mathrm{E2}$; b1, $0.03125 \times 10^{-4} \mathrm{M} \mathrm{E2} 2 \mathrm{c} 1,0.0625 \times 10^{-4} \mathrm{M} \mathrm{E2} ; \mathrm{d} 1,0.125 \times 10^{-4} \mathrm{M}$ E2; e1, $0.25 \times 10^{-4} \mathrm{M} \mathrm{E2;} \mathrm{f1,} 0.5 \times 10^{-4} \mathrm{M} \mathrm{E2;} \mathrm{g1,} 1 \times 10^{-4} \mathrm{M} \mathrm{E2}$. TAM significantly inhibited the migration capabilities of DLD-1 cells in a dose-dependent manner ( ${ }^{\prime \prime} \mathrm{P}<0.05$, comparisons were made between all concentrations in the TAM group); a2, $0.015625 \times 10^{-3} \mathrm{M} \mathrm{TAM}^{-} \mathrm{b} 2,0.03125 \times 10^{-3} \mathrm{M} \mathrm{TAM} ; \mathrm{c} 2,0.0625 \times 10^{-3} \mathrm{M} \mathrm{TAM}$; $\mathrm{d} 2,0.125 \times 10^{-3} \mathrm{M}$ TAM; e2, $0.25 \times 10^{-3} \mathrm{M}$ TAM. Combination-treatment significantly inhibited the migration capabilities of DLD-1 cells in a dose-dependent manner ("P<0.05, comparisons were made between all concentrations in the TAM+E2 group); a3, a1+a2; b3, b1+b2; c3, c1+c2; d3, d1+d2. The inhibitory effect of combined treatment on cell migration was significantly greater than that observed in each individual treatment alone [ ${ }^{\circledR} \mathrm{P}<0.05$, TAM+E2 vs. the individual treatment groups (E2 and TAM treatment alone)]. Cell migration capabilities in the control group were significantly greater when compared to the E2, TAM and combined treatment, respectively $\left({ }^{+} \mathrm{P}<0.05\right.$, control vs. each treatment group). (B) Representative light microscope images (magnification, $\mathrm{x} 40$ ) were used to evaluate the effect of E2, TAM and E2+TAM combined drug treatments on cell migration. TAM, tamoxifen; E2, 17M, tamoxifen.

prognosis of tumors (44). The results of the present study indicated that TAM possesses apoptosis-promoting functions. Therefore, the authors investigated whether TAM and E2 may affect the expression of survivin and cyclin D1. Li et al (29) previously demonstrated that TAM may inhibit the expression of the survivin gene to relieve the inhibitory effect of survivin on caspase- 3 and therefore increase caspase- 3 activity, which leads to apoptosis induction in breast cancer cells. In addition, a previous study demonstrated that TAM decreases the number of cells in S phase by decreasing the ratio of cells in the $\mathrm{G}_{2} / \mathrm{M}$ phases of the cell cycle, thus decreasing the expression of survivin (45). Previous studies have demonstrated via immunohistochemical analyses, that the normal colorectal mucosa does not express survivin $(46,47)$. With the transition from 
normal colorectal mucosa to low-grade dysplastic adenoma and highly dysplastic adenoma/CRC, the positive rate of survivin expression consequently increased. Wang et al (41) transfected a recombinant adenovirus containing survivin into SW480 cells, which led to a significant decrease in survivin mRNA expression. Once survivin was silenced, the percentage of apoptotic cells was observed to increase. It has therefore been postulated that silencing of survivin expression may inhibit cell growth and induce apoptosis in CRC cells. The results of the present study demonstrated that survivin protein expression decreased to some extent following treatment of DLD-1 cells with TAM; the degree of which was positively associated with drug concentration and treatment duration. Therefore, the authors hypothesized that the downregulation of survivin expression induced by TAM occurs in a time- and dose-dependent manner. TAM downregulated survivin expression in DLD-1 cells and induced CRC cell apoptosis. It was speculated that the mechanism underlying the induction of apoptosis by TAM may have been associated with survivin expression. In addition, following treatment of DLD-1 cells with different concentrations of E2, the survivin protein expression levels were not significantly altered in the $24 \mathrm{~h}$ treatment group; however, it increased with increasing drug concentrations in the 48 and $72 \mathrm{~h}$ groups. Higher levels of survivin protein expression following treatment with medium concentrations of E2 were observed, whereas lower levels of expression were observed following treatment with high and low E2 concentrations. However, following treatment of cells with E2, survivin mRNA expression levels were reduced. The extent of this decrease was positively associated with the concentration of drug and duration of treatment. He et al (48) demonstrated that estrogen promotes the $G_{2}$ to $\mathrm{S}$ phase transition in ovarian cancer cell lines. In addition, with increasing doses of estrogen, the number of cells in $G_{1}$ phase was not significantly altered; however, the number of cells transitioning from $\mathrm{G}_{2}$ to $\mathrm{S}$ phase increased. The apoptosis-inhibition factor survivin is primarily expressed in the $G_{2}$ phase. He et al (48) demonstrated that, when E2 concentration increased, survivin expression was decreased accordingly. These results are consistent with the results of the present study regarding survivin mRNA levels following E2 treatment, however this is not consistent with the survivin protein expression levels. A possible explanation for these conflicting results may be that the expression of the ER is different among different cell lines. Whether different survivin expression levels are induced by the expression of different ER subtypes will be the focus of future studies. Hwang et al (49) and an additional study (50) previously demonstrated that TAM downregulated cyclin D1 expression in vitro in ER-positive MCF-7 human breast cancer cells and rat breast cancer cells to inhibit tumor development. However, the present study indicated that following drug treatment in three different groups, the expression levels of cyclin D1 mRNA and protein were not altered. It is possible that, following the interaction of TAM with ER $\alpha$, transcription is interrupted and the expression of cyclin D1 mRNA and protein are downregulated, thus blocking the $\mathrm{G}_{1} / \mathrm{S}$ transition. However, as the DLD-1 cells employed in the present study expressed ER $\beta$ alone, TAM may have elicited little effect on cyclin D1 protein expression.
In conclusion, the results of the present study demonstrated that TAM effectively inhibited the viability and migration ability of DLD-1 colorectal cells and promoted apoptosis. A high concentration of E2 demonstrated inhibitory effects on the viability of the DLD-1 cells, and TAM and E2 may synergistically inhibit cell viability. The inhibitory effect of TAM plus E2 treatment was greater than that of each agent alone. In addition, the anticancer effects of TAM and E2 may be associated with the downregulation of survivin expression. These results provide a novel experimental basis for hormonal adjuvant therapy in the treatment of CRC. Based on these results, the authors aim to conduct in vivo animal studies to provide an experimental basis for final randomized controlled clinical trials.

\section{Acknowledgements}

The present study was supported by the National Natural Science Foundation of the Republic of China (grant no. 81101861), the Doctoral Fund of the Ministry of Education of China (grant no. 20110171120100), the Natural Science Foundation of Guangdong Province (grant no. S2012010011132), the Science and Technology Planning Project of Guangdong Province (grant no. 2013B021800146) and Guangzhou Science and Technology Plan Projects (Health Medical Collaborative Innovation Program of Guangzhou) (grant no. 201400000001-4). The authenticity of this article has been validated by uploading the key raw data onto the Research Data Deposit public platform (www. researchdata.org.cn), with the approval number as RDDB 2017000056.

\section{References}

1. Pan F, Bao YH, Huang RY, Li J and Zhang Z: Epidemiological study on the incidence of large intestine cancer in Wenzhou city from 2001 to 2005. Zhonghua Zhongliu Fangzhi Zazhi 14: 1286-1287, 2007 (In Chinese).

2. Chen WQ, Zheng RS, Zhang SW, Li N, Zhao P, Li GL, Wu LY and He J: Report of incidence and mortality in China cancer registries, 2008. Chin J Cancer Res 24: 171-180, 2012.

3. László L: Predictive and prognostric factors in the complex treatment of patients with colorectal cancer. Magy Onkol 54: 383-394, 2010.

4. Meyerhardt JA and Mayer RJ: Systemic therapy for colorectal cancer. N Engl J Med 352: 476-487, 2005.

5. Zhang J, Xu J, Zhang RX, Zhang Y, Ou QJ, Li JQ, Jiang ZZ, Wu XJ, Fang YJ and Zheng L: CD169 identifies an activated CD8(+) T cell subset in regional lymph nodes that predicts favorable prognosis in colorectal cancer patients. Oncoimmunology 5: e1177690, 2016.

6. Jensen EV, Block GE, Smith S, Kyser K and DeSombre ER: Estrogen receptors and breast cancer response to adrenalectomy. Natl Cancer Inst Monogr 34: 55-70, 1971.

7. Jordan VC, Gapstur S and Morrow M: Selective estrogen receptor modulation and reduction in risk of breast cancer, osteoporosis, and coronary heart disease. J Natl Cancer Inst 93: 1449-1457, 2001.

8. Couse JF, Lindzey J, Grandien K, Gustafsson JA and Korach KS: Tissue distribution and quantitative analysis of estrogen receptor-alpha (ERalpha) and estrogen receptor-beta (ERbeta) messenger ribonucleic acid in the wild-type and ERalpha-knockout mouse. Endocrinology 138: 4613-4621, 1997.

9. Paech K, Webb P, Kuiper GG, Nilsson S, Gustafsson J, Kushner PJ and Scanlan TS: Differential ligand activation of estrogen receptors ERalpha and ERbeta at AP1 sites. Science 277: 1508-1510, 1997. 
10. Enmark E, Pelto-Huikko M, Grandien K, Lagercrantz S, Lagercrantz J, Fried G, Nordenskjöld $M$ and Gustafsson JA: Human estrogen receptor beta-gene structure, chromosomal localization, and expression pattern. J Clin Endocrinol Metab 82: 4258-4265, 1997.

11. Campbell-Thompson M, Lynch IJ and Bhardwaj B: Expression of estrogen receptor (ER) subtypes and ERbeta isoforms in colon cancer. Cancer Res 61: 632-640, 2001.

12. Takeyama J, Suzuki T, Inoue S, Kaneko C, Nagura H, Harada N and Sasano H: Expression and cellular localization of estrogen receptors alpha and beta in the human fetus. J Clin Endocrinol Metab 86: 2258-2262, 2001.

13. Singh S and Langman MJ: Oestrogen and colonic epithelial cell growth. Gut 37: 737-739, 1995.

14. Grodstein F, Newcomb PA and Stampfer MJ: Postmenopausal hormone therapy and the risk of colorectal cancer: A review and meta-analysis. Am J Med 106: 574-582, 1999.

15. Fiorelli G, Picariello L, Martineti V, Tonelli F and Brandi ML: Functional estrogen receptor beta in colon cancer cells. Biochem Biophys Res Commun 261: 521-527, 1999.

16. Arai N, Ström A, Rafter JJ and Gustafsson JA: Estrogen receptor beta mRNA in colon cancer cells: Growth effects of estrogen and genistein. Biochem Biophys Res Commun 270: 425-431, 2000.

17. Smith CL, Nawaz Z and O'Malley BW: Coactivator and corepressor regulation of the agonist/antagonist activity of the mixed antiestrogen, 4-hydroxytamoxifen. Mol Endocrinol 11: 657-666, 1997

18. Shao R, Feng Y, Zou S, Weijdegård B, Wu G, Brännström $M$ and Billig H: The role of estrogen in the pathophysiology of tubal ectopic pregnancy. Am J Transl Res 4: 269-278, 2012.

19. Siegel RL, Miller KD and Jemal A: Cancer statistics, 2016. CA Cancer J Clin 66: 7-30, 2016.

20. Chen W, Zheng R, Baade PD, Zhang S, Zeng H, Bray F, Jemal A, Yu XQ and He J: Cancer statistics in China, 2015. CA Cancer J Clin 66: 115-132, 2016.

21. Chute CG, Willett WC, Colditz GA, Stampfer MJ, Rosner B and Speizer FE: A prospective study of reproductive history and exogenous estrogens on the risk of colorectal cancer in women. Epidemiology 2: 201-207, 1991.

22. Calle EE, Miracle-McMahill HL, Thun MJ and Heath CW Jr: Estrogen replacement therapy and risk of fatal colon cancer in a prospective cohort of postmenopausal women. J Natl Cancer Inst 87: 517-523, 1995.

23. English MA, Kane KF, Cruickshank N, Langman MJ, Stewart PM and Hewison M: Loss of estrogen inactivation in colonic cancer. J Clin Endocrinol Metab 84: 2080-2085, 1999.

24. Oduwole OO, Isomaa VV, Nokelainen PA, Stenbäck F and Vihko PT: Downregulation of estrogen-metabolizing 17 beta-hydroxysteroid dehydrogenase type 2 expression correlates inversely with Ki67 proliferation marker in colon-cancer development. Int J Cancer 97: 1-6, 2002.

25. Neuhouser ML, Aragaki AK, Prentice RL, Manson JE, Chlebowski R, Carty CL, Ochs-Balcom HM, Thomson CA, Caan BJ, Tinker LF, et al: Overweight, obesity, and postmenopausal invasive breast cancer risk: A secondary analysis of the women's health initiative randomized clinical trials. JAMA Oncol 1: 611-621, 2015.

26. Chlebowski RT, Wactawski-Wende J, Ritenbaugh C, Hubbell FA, Ascensao J, Rodabough RJ, Rosenberg CA, Taylor VM, Harris R, Chen $\mathrm{C}$, et al: Estrogen plus progestin and colorectal cancer in postmenopausal women. N Engl J Med 350: 991-1004, 2004.

27. Rossouw JE, Anderson GL, Prentice RL, LaCroix AZ, Kooperberg C, Stefanick ML, Jackson RD, Beresford SA, Howard BV, Johnson KC, et al: Risks and benefits of estrogen plus progestin in healthy postmenopausal women: Principal results from the women's health initiative randomized controlled trial. JAMA 288: 321-333, 2002.

28. Paruthiyil S, Parmar H, Kerekatte V, Cunha GR, Firestone GL and Leitman DC: Estrogen receptor beta inhibits human breast cancer cell proliferation and tumor formation by causing a G2 cell cycle arrest. Cancer Res 64: 423-428, 2004.

29. Li YH, Wang C, Meng K, Chen LB and Zhou XJ: Influence of survivin and caspase- 3 on cell apoptosis and prognosis in gastric carcinoma. World J Gastroenterol 10: 1984-1988, 2004.

30. Hendrickse CW, Jones CE, Donovan IA, Neoptolemos JP and Baker PR: Oestrogen and progesterone receptors in colorectal cancer and human colonic cancer cell lines. Br J Surg 80: 636-640, 1993
31. Fox EM, Davis RJ and Shupnik MA: ERbeta in breast cancer-onlooker, passive player, or active protector? Steroids 73: 1039-1051, 2008.

32. Miller WR, Anderson TJ, Dixon JM and Saunders PT: Oestrogen receptor beta and neoadjuvant therapy with tamoxifen: Prediction of response and effects of treatment. Br J Cancer 94: 1333-1338, 2006.

33. Rivera-Guevara $\mathrm{C}$ and Camacho J: Tamoxifen and its new derivatives in cancer research. Recent Pat Anticancer Drug Discov 6: 237-245, 2011.

34. Garrido JM, Manuela E, Garrido PJ, Oliveira-Brett AM and Borges F: An electrochemical outlook on tamoxifen biotransformation: Current and future prospects. Curr Drug Metab 12: 372-382, 2011.

35. Krishnan K, Campbell S, Abdel-Rahman F, Whaley S and Stone WL: Cancer chemoprevention drug targets. Curr Drug Targets 4: 45-54, 2003.

36. Hou YF, Yuan ST, Li HC, Wu J, Lu JS, Liu G, Lu LJ, Shen ZZ, Ding J and Shao ZM: ERbeta exerts multiple stimulative effects on human breast carcinoma cells. Oncogene 23: 5799-5806, 2004.

37. Onozato W, Yamashita K, Yamashita K, Kuba T, Katoh H, Nakamura T, Sato T, Ihara A, Okayasu I and Watanabe M: Genetic alterations of K-ras may reflect prognosis in stage III colon cancer patients below 60 years of age. J Surg Oncol 103: 25-33, 2011

38. Sharrard RM, Royds JA, Rogers S and Shorthouse AJ: Patterns of methylation of the c-myc gene in human colorectal cancer progression. Br J Cancer 65: 667-672, 1992.

39. Sun N, Meng Q and Tian A: Expressions of the anti-apoptotic genes Bag-1 and Bcl-2 in colon cancer and their relationship. Am J Surg 200: 341-345, 2010.

40. Roger L, Jullien L, Gire V and Roux P: Gain of oncogenic function of p53 mutants regulates E-cadherin expression uncoupled from cell invasion in colon cancer cells. J Cell Sci 123: 1295-1305, 2010.

41. Wang XH, Fu ZX, Zhao Y, Shen W, Wu X and Wang C: Survivin: An overexpression protein with notable cellular localization and multiple roles in colon cancer. Chinese-German J Clin Oncol 9: 519-523, 2010.

42. Garg H, Suri P, Gupta JC, Talwar GP and Dubey S: Survivin: A unique target for tumor therapy. Cancer Cell Int 16: 49,2016.

43. Scantlebury JB, Luo J, Thorstad WL, El-Mofty SK and Lewis JS Jr: Cyclin D1-a prognostic marker in oropharyngeal squamous cell carcinoma that is tightly associated with high-risk human papillomavirus status. Hum Pathol 44: 1672-1680, 2013.

44. El-Hafez AA, El Aaty Shawky A and Hasan B: Cyclin D1 overexpression associates with favourable prognostic factors in invasive breast carcinoma. Cancer Biomark 12: 149-154, 2012.

45. Zhang GJ, Kimijima I, Onda M, Kanno M, Sato H, Watanabe T, Tsuchiya A, Abe R and Takenoshita S: Tamoxifen-induced apoptosis in breast cancer cells relates to down-regulation of bcl-2, but not bax and bcl-X(L), without alteration of p53 protein levels. Clin Cancer Res 5: 2971-2977, 1999.

46. Lin LJ, Zheng CQ, Jin Y, Ma Y, Jiang WG and Ma T: Expression of survivin protein in human colorectal carcinogenesis. World J Gastroenterol 9: 974-977, 2003.

47. Fang YJ, Lu ZH, Wang GQ, Pan ZZ, Zhou ZW, Yun JP, Zhang MF and Wan DS: Elevated expressions of MMP7, TROP2, and survivin are associated with survival, disease recurrence, and liver metastasis of colon cancer. Int J Colorectal Dis 24: 875-884, 2009.

48. He Q, Liang CH and Lippard SJ: Steroid hormones induce HMG1 overexpression and sensitize breast cancer cells to cisplatin and carboplatin. Proc Natl Acad Sci USA 97: 5768-5772, 2000.

49. Hwang TS, Han HS, Hong YC, Lee HJ and Paik NS: Prognostic value of combined analysis of cyclin D1 and estrogen receptor status in breast cancer patients. Pathol Int 53: 74-80, 2003.

50. Kdroxenidou L, Ohlson LC and Porsch-Hällström I: Long-term 17 a1pha-ethinyl estradiol treatment decreses cyclin E and cdlc2 expression, reduces cdk2 kinase activity and inhibits $\mathrm{S}$ phase entry in regenerating rat liver. J Hepatol 43: 478-484, 2005. 